PATTINGALLOANG

(C) Jurnal Pemikiran Pendidikan dan Penelitian Kesejarahan

\title{
Reaksi Sultan dan Masyarakatnya terhadap Pendudukan Militer Jepang di Bima
}

\author{
Yusuf $^{1}$ \\ 'Guru SMA Negeri 2 Langgudu Kabupaten Bima Nusa Tenggara Barat \\ 'y.yusuf30@yahoo.com
}

\begin{abstract}
Abstrak
Penelitian ini bertujuan untuk mendeskripsikan latar belakang Jepang di Bima dan reaksi Sultan dan masyarakat Bima terhadap kedatangan Jepang serta dampaknya terhadap masyarakat. Penelitian ini menggunakan pendekatan ilmu sejarah, sehingga tahap penelitian yang dilakukan adalah (1) Heuristik atau pengumpulan data, (2) Kritik (3) Interprtasi dan (4) Historiografi. Hasil penelitian menunjukkan bahwa bahwa Berdasarkan pada pembagian wilayah kontrol pendudukan Jepang di Bima bahwa kawasan Indonesia bagian timur berada di bawah kontrol Armada (Angkatan) Laut yang berpusat di Makassar. Setelah menduduki Sulawesi Selatan pada tanggal 9 Februari 1942, Jepang terus melakukan gerak invasinya ke Nusa Tenggara, antara lain Kupang di Nusa Tenggara Timur (NTT) serta Bima di Kepulauan Sumbawa. Armada Laut Jepang dibawah pimpinan Kolonel Saito mendarat di Pelabuhan Bima pada tanggal 17 Juli 1942. Kedatangannya di sambut baik oleh penduduk setempat, sekalipun mereka (masyarakat Bima) di selimuti rasa khawatir atas rencana Asisten Residen Belanda, H.E. Haak untuk kembali berkuasa di Bima, karena itu dengan mudah Jepang menduduki Bima. Dampak keberadaan Jepang di Bima dibidang sosial diantaranya terjadi keresahan sosial dan porak-porandanya tata kehidupan sosial masyarakat. Agama dan adat yang selama ini dijunjung tinggi oleh masyarakat "terpaksa" harus dilanggar. Sementara dampak dibidang Ekonomi, berupa keterpurukkan Ekomomi, sebab masyarakat tidak lagi mencurahkan perhatian sepenuhnya untuk mengolah lahan pertaniannya. Penderitaan masyarakat berakhir setelah Jepang kalah dan menyerah tanpa syarat kepada sekutu pada bulan Agustus 1945. Sejak itu, pemerintahan pendudukan Jepang berakhir di Bima khususnya dan Indonesia pada umumnya.
\end{abstract}

Kata Kunci: Pendudukan, Japang di Bima

\section{Abstract}

This study aims to describe the background of Japan in Bima and the reaction of the Sultan and the people of Bima to the arrival of Japan and its impact on society. This study uses a historical science approach, so the stages of research carried out are (1) Heuristics or data collection, (2) Criticism (3) Interpretation and (4) Historiography. The results showed that based on the division of the Japanese occupation control area in Bima that the eastern part of Indonesia was under the control of the Naval Fleet (Force) based in Makassar. After occupying South Sulawesi on February 9, 1942, Japan continued to make its invasion moves to Nusa Tenggara, including Kupang in East Nusa Tenggara (NTT) and Bima in the Sumbawa Islands. The Japanese Sea Fleet under the leadership of Colonel Saito landed at the Port of Bima on July 17, 1942. His arrival was welcomed by local residents, even though they (the Bima people) were shrouded in worry over the plan of the Assistant Resident of the Netherlands, H.E. Haak to return to power in Bima, because it easily 
Japan occupied Bima. The impact of the existence of Japan in Bima in the social field included social unrest and ruins of the social order of the community. Religion and customs that have been upheld by the community are "forced" to be violated. While the impact on the economy, in the form of deterioration in the economy, is because the community no longer pays full attention to cultivate its agricultural land. The suffering of the people ended after Japan's defeat and surrender unconditionally to the allies in August 1945. Since then, the Japanese occupation government ended in Bima in particular and Indonesia in general.

Keywords: Occupation, Japanese in Bima

\section{A. Pendahuluan}

Pada tanggal 17 Juli 1942, pasukan Militer Angkatan Laut Jepang dibawah pimpinan Kolonel Saito mendarat di pelabuhan Bima. Pasukan Militer Jepang ini merupakan Pasukan dari Armada Laut Selatan kedua yang berkedudukan pusat di Makassar. "Dengan kehadiran MIliter Jepang ini Fase baru sejarah daerah Bima dimulai" (Ismail, 1996). Ditinjau dari segi goegrafis dan strategi pendudukan, daerah Bima tampak sangat strategis bagi Jepang sebagai loncatan bufferstate untuk melakukan gerak pendudukannya ke Australia dan daerahdaerah lainnya di Indonesia. Puluhan ribu tentara Jepang disiagakan di Bima, yang sebagian besarnya berada di daerah Rompo Karumbu yang terletak di wilayah bagian selatan Bima (Pulau Sumbawa), pantai Timur Lautan Hindia. Kehadiran Militer Jepang di Bima oleh (Tajib, 1995), melukiskan dengan kata-kata sebagai berikut:

“.... dari pelabuhan Bima (Pelabuhan Muhammad Salahuddin) bala tentara Jepang dengan berjalan kaki, jalan menguasai ruas jalanan, mereka didahului oleh pasukan pelopor bersepeda motor. Sementara mobil Kolonel Sairo melaju dengan pelanpelan menuju Istana Kesultanan Bima”

Kehadiran mereka pada awalnya begitu membahagiakan hati dan perasaan Sultan beserta Masyarakat Bima (Dou Dana Mbojo). Sebab, ketika itu ada rencana Asisten Residen pemerintahan Hindia
Belanda, H. E. Haak yang memiliki keinginan untuk mengambil kembali tumpuk kekuasaan atas wilayah Kesultanan Bima. Berbeda dengan daerah lainnya, kehadiran tentara Jepang di Bima tidak mendapat perlawanan dari pemerintahan Hindia Belanda (Tentara KNIL), sebab sebelumnya para orang-orang kafir kulit putih itu telah berhasil diusir oleh Laskar Bima pada bulan April 1942. Hal ini tampak memberikan kemudahan bagi Jepang ketika memulai gerak pendudukannya di daerah ini. Namun, seperti halnya pula wilayah-wilayah lainnya di Indonesia, pendudukan Militer Jepang di wilayah ini didasari oleh kepentingan ekonomi, yakni untuk memeperoleh bahan baku industri guna memperkuat segala sesuatu (terutama bidang militer) dalam rengka menghadapi perang Asia Timur Raya. Untuk mencapai tujuannya tersebut, berbagai propaganda dilakukkan, yang pada hakikatnya bagaimana mereka dapat menarik perhatian penduduk pribumi, tempat yang menjadi sasaran eksploitasi.

Salah satu bentuk propaganda yang dilakukannya ialah keinginan untuk menghilangkan seluruh unsur Barat dari Daratan Asia (Termasuk Indonesia). Padahal, sesungguhnya Jepang justru merupakan negara Kapitalis-Fasis yang sangat berbahaya. Hal itu dapat di simak pada petikan kalimat berikut :

"Mereka mengindoktirinasi, melatih dan mempersenjatai banyak dari generasi muda serta memberi kesempatan kepada pemimpin yang 
lebih tua (antara lain Soekarno) untuk menjalin hubungan dengan rakyat. Di seluruh Nusantara, mereka pun mempolitisasikan bangsa Indonesia sampai pada tingkat desa dengan sengaja dan dengan menghadapkan Indonesia pada rezim Kolonial yang bersifat sangat menindas dan merusak dalam sejarahnya. Dengan demikian, desadesa secara keras digoncang dengan kelesuan dan isolasi politik dari akhir periode Belanda, dan andaikan jika Jepang tidak kalah perang dan pembentukan kawasan Asia Timur Raya Tercapai, maka sedikit harapan bagi kemerdekaan Indonesia yang sesungguhnya” (Ricklefs, 1995)

Hal tersebut diatas menunjukkan bahwa kehadiran Militer Jepang di Indonesia tidak sungguh-sungguh mengusir Belanda, akan tetapi ada keinginan lain yang ingin mereka dapatkan (Hiden Agenda). Maka dari itu, mereka berusaha tampil dengan gaya yang sangat menawan. Fakta sejarah membuktikan bahwa setelah empat bulan pendudukannya terjadi eksploitasi besar-besaran terhadap hasil alam Indonesia dalam rangka persiapan sumber daya ekonomi menghadapi Perang Asia Timur Raya.

Sedangkan tindakannya itu dikalangan masyarakat Bima mulai dilakukan pada bulan ke dua (Agustus 1942), yang terhitung sejak awal kedatangan (Juli 1942) dalam masa pendudukannya, mereka banyak melakukan eksploitasi atas harta milik penduduk (mulai dari hasil peternakan, perkebunan, dan bahkan sampai pada besi tua sekalipun di kumpulkan) yang dikoordinir oleh para Kempei Tai Melayu (Polisi Pribumi). Hal tersebut diperkuat dengan hasil wawancara (Zakaria, 29 Mei 2005) sebagaimana dalam kutipan berikut ini :

"Ipikai susa re anae...wunga edere, wara ku Dae Muna Robo, lu’u karawi labo Nipo ma labo Ama Mida, ndadi sarati ra janga ra sahe na weha sara'a weaku, au pawali bongi ra jago re ni, nakaboro sara'aku ta dou ede rasa ke”

Artinya : "Yang membuat susah waktu itu adalah ada orang yang bernama Dae Muna Robo menjadi kaki tangan Jepang bersama dengan Ama Mida. Jadi, bebek, ayam, dan kerbau di ambilnya, apalagi beras dan jagung, semuanya di kumpulkan dari penduduk sekampung”

Petikan kalimat di atas minimal dapat memberikan gambaran betapa susahnya kehidupan masyarakat Bima pada pendudukan masyarakat Jepang dengan berbagai praktek yang dijalankannya, namun di situ juga dapat kita melihat adanya campur tangan warga pribumi yang dijadikan oleh pihak Jepang sebagai kaki-tangannya (mandor) dalam setiap melakukan tindakantindakan yang menyentuh dengan rakyat. Berbagai peristiwa yang terjadi telah meninggalkan kesan kolektif (Memory Colective) bagi masyarakat Bima sampai sekarang.

Salah satu peristiwa yang cukup memilukan masyarakat Bima pada waktu itu ialah "belum beberapa lama Jepang menduduki daerah ini, mereka sudah mulai memberlakukan hukuman cambuk sampai mati yang seperti halnya mereka lakukan di Jepang" (Tajib, 1995, hal. 321). Mengenai hukuman cambuk sampai mati ini berikut tergambarkan dari hasil wawancara dengan salah seorang saksi sejarah :

"Hukuman cambuk sampai mati oleh orang Jepang pertama kalinya dilakukan terhadap seorang rakyat yang bernama La Kahi, yang pada saat itu mencari besi tua di kantor pemerintahan. Untuk La Kahi ini, orang Jepang menghukum tampa diperiksa terlebih dahulu. Ia langsung dihukum, dicambuk didepan rumah tinggalnya (kediaman) pimpinan Jepang (Kolonel Saito) di Pandopo. 
Ia dicambuk dihadapan puluhan warga yang ketika itu langsung melihat hukuman yang dilakukan kepada La Kahi. Semua yang melihat kejadian itu rata-rata meneteskan air matanya. Biarpun Dia telah pingsan, orang Jepang menyiramnya dengan air sampai akhirnya sadar kembali, kemudian hukumanpun dilanjutkan. Begitulah seterusnya, sampai ajalnya tiba atau meninggal. Setelah hukuman tersebut selesai, orang Jepang kembali memberitahukan (dengan nada tegas yang memaksa) kepada masyarakat yang menyaksikan atau melihat jalannya (Prosesi) hukuman itu dengan kalimat : Siapa saja yang melakukan hal yang sama maka hukumnnyapun akan sama seperti apa yang anda sekalian lihat dan saksikan tadi. Hukuman demi hukuman terus dilakukan oleh orang Jepang terhadap masyarakat yang dianggapnya bersalah tampa melalui peradilan sebelumnya atau pemeriksaan yang diperuntukkan kepada masyarakat selama masa pemerintahannya. (Hakim, 4 Juni 2005).

Berdasarkan kesaksian diatas, nampak jelas bentuk penjajahan yang dilakukan oleh Saudara Tua (Jepang) terhadap saudara mudanya. Hal itu lebih diperburuk lagi oleh adanya tindakantindakan pengambil alihan kekuasaan, perampasan hak-hak penduduk (Termasuk Hak Azazi Manusia) dan eksploitasi sumber daya alam yang semakin mengokohkan wajah penjajah yang sesungguhnya yang telah mereka miliki. Hal itu menimbulkan kesengsaraan, kegelisahan dan ketidak nyamanan bagi masyarakat setiap harinya, karena dihantui oleh berbagai perasaan yang menakutkan terutama bila bertemu dengan pasukan tentara Jepang.

\section{B. Metode Penelitian}

Metode penelitian dilakukan dengan 4 tahapan yakni; 1) Heuristik pencarian serta pengumpulan sumber yang berkaitan dengan masalah atau objek yang ditulis dalam hal ini yang berkaitan dengan penelitian, dan pengumpulan data sekunder dari beberapa buku yang diperoh dari Perpustakaan Wilayah Nusa Teggara Barat dan Timur, Perpustakaan Kabupaten Bima Badan Pusat Statistik Kabupaten Bima, kemudian diperkuat melalui kegiatan oservasi atau penelitian lapangan melalui tahap wawancara. 2) Kritik dimana Setelah pengumpulan data maka langkah selanjutnya yang dilakukan adalah krtitik sumber. menyaringnya secara kritik agar terjaring fakta yang menjadi pilihannya. Langkah-langkah inilah yang disebut kritik sumber (Sjamsuddin, 2012), 3) Interpretasi

Fakta-fakta sejarah yang berhasil dikumpulkan belum banyak bercerita faktafakta tersebut harus disusun dan digabungkan sehingga membentuk cerita peristiwa sejarah proses ini disebut dengan interpretasi. (Madjid, 2014) dan 4) Historiografi yakni merupakan tahap akhir dari penelitian sejarah, setelah melalui fase heuristik, kritik, dan interpretasi.Pada tahap terakhir inilah penulisan sejarah dilakukan. Pada tahap ini fakta-fakta yang telah dirumuskan atau diinterpretasikan mengenai kedatangan Jepan di Bima dan reaksi Sultan dan Masyarakat Bima serta dampaknya.

\section{Hasil dan Pembahasan}

1. Reaksi Sultan Dan Masyarakat Bima Terhadap Pendudukan Militer Jepang

Pada awal kedatangannya (Jepang), para pemimpin rakyat di berbagai daerah di Indonesia menerima dengan baik kehadiran mereka. Sebab, Jepang mempropagandakan lingkungan persemakmuran Asia Timur Raya sebagaimana termaktub dalam semboyan Hokka-ichi-u yang pernah diperintahkan oleh Jimmo Tenno bahwa bangsa Jepang merupakan keluarga yang sah (bangsa lain 
tidak) dan berhak atas seluruh dunia agar dunia dapat disusunya sebagai satu keluarga dan Jepang sebagai pemimpin. (Soebantardjo, 1962, hal. 14-15).

Propaganda yang dilakukan Jepang antara lain memberikan janji kemerdekaan bagi bangsa Indonesia kelak dikemudian hari, sekalipun menjelang kekalahannya dalam perang pasifik janji itu dibatalkan dan keinginannya untuk menghilangkan semua unsur perjanjian bangsa Barat (Eropa), yakni Belanda yang menjajah Indonesia ketika itu. "Untuk meyakinkan bangsa Indonesia akan propaganda-propaganda yang dilakukannya, Jepang membentuk sejumlah organisasi baik polotik (propaganda) maupun militter atau ketentaraan” (Notosusanto, 1992, hal. 27).

Ramalan Jayabaya mengenai kedatangan bangsa kulit kuning (Jepang) di Indonesia hanya seumur Jagung dijadikannya juga sebagai salah satu upaya untuk meyakinkan keberadannya. hal itu sebagimana yang dijelaskan oleh (Kertaparti, 2000, hal. 9) bahwa "Setelah seumur jagung (1000 hari) ..... Jepang akan kembali ke negerinya dan mengembalikan bangsa Indonesia kepada bangsa Indonesia sendiri”. Jika demikian, berarti bahwa masa penjajahan di Indonesia akan segera berakhir dan tinggal menunggu waktunya saja. Hal tersebut membuat masyarakat Indonesia, terlebih lagi Bima, percaya bahwa Jepang merupakan pembebas bagi bangsa Indonesia. Hal itu semakin diperkuat pula dengan upaya Jepang dalam mengambil alih tumpuk kekuasaan (pemerintahan) atas Indonesia dari tangan Belanda yang terjadi hampir merata di seluruh wilayah Indonesia.

Oleh karena itu, kedatangan merekapun di daerah Bima mendapat respon positif dari penguasa (Sultan) dan masyarakat Bima, tanpa adanya kecurigaan-kecurigaan sekalipun. Sebab, tampak janji itu begitu meyakinkan dan membuat masyarakat Bima terbuai oleh janji-janji manis Jepang pada awal pendudukannya. Sikap pertama kalinya yang ditunjukkan Jepang atas niat baiknya itu ditunjukkan melalui tindakan-tindakannya antara lain memberikan pujian dan penghargaan kepada Laskar Bima setelah melalui serangkaian perlawanan terhadap pemerintahan Hindia Belanda di daerahnya. Kendatipun demikian, ternyata kenyataan di kemudian menunjukkan lain. Niat suci Jepang itu ternyata di balut oleh kepentingan Ekspansionis yang lebih memebahayakan kehidupan Masyarkat Bima. Sikap rakyat Bima yang sebelumnya simpati dengan kedatangan Jepang akhirnya harus berbalik menjadi sikap yang antipati setelah pemerintah Militer Jepang menurunkan Bendera Kesultanan Bima. Namun Masyarakat Bima ketika itu tidak dapat memberikan perlawanan, sebab mereka tidak mencurigai akal busuk dari pemerintah pendudukan Jepang. Disamping kekuatan yang tidak mendukung untuk melakukan perlawanan terhadap tindakan yang dilakukan pemerintah militer Jepang itu.

"Seandainya waktu penurunan bendera itu kami bersama-sama langsung melawannya, mungkin kami akan berhasil memepertahankan posisi bendera Kesultanan, namun kami tidak punya persiapan sebelumnya, karena mereka memperlihatkan wajah-wajah simpati kepada masyarakat” (Jafar, 2005).

Sikap antipati yang kedua kalinya pun muncul ketika Jepang ingin meminta dan mengambil gadis-gadis Bima untuk dijadikan sebagai pekerja di bar-bar dan melayani hawa nafsu (kepuasan) tentara-tentara Jepang. Secara spontan permintaan itu ditolak oleh masyarakat dan juga oleh pemerintahan Kesultanan Bima, sebab tidak sesuai dengan adat istiadat dan norma kehidupan seharihari, lebih-lebih pola kehidupan masyarakat yang menjunjung tinggi nilai-nilai Islam dan tatanan adat masyarakat Bima. Hal ini merupakan suatu pelaggaran dan sekaligus penghinaan bagi masyarakat Bima. Mengenai bentuk reaksi masyarakat dan pemerintahan 
Kesultanan Bima pada saat itu, dapat disimak pada petikan kelimat berikut : "Menanggapi permintaan yang aneh itu, Sultan Muhammad Salahuddin berkonsultasi dengan Jeneli Rasa Na`e Abdul Muthalib dan kepala kampung Mpangga Wawi menghadap pemerintah Militer Jepang. Mereka kemudian menyerahkan keris terhunus dan bukannya gadis-gadis Bima (yang dikehendaki Jepang). (Tajib, 1995, hal. 325). Selain reaksi dari sultan dan beberapa tokoh masyarakat, salah satu solusi yang dipilih masyarakat adalah melakukan Nika Baronta atau Nikah Berontak. Nika Baronta (Nikah Berontak) adalah menikah secara berontak. Dimana para orang dua gadis sibuk mencarikan calon suami bagi anak gadisnya, tanpa memandang apakah pria itu sudah berkeluarga atau tidak, bahkan duda sekalipun. Dicarikanlah pasangan dari keluarga-keluarga dekat, yang penting menikah. Karena apabila masih gadis, kemungkinan besar akan dirampas oleh tentara Jepang untuk dijadikan obyek pengumbar nafsunya.

Disini tampak sudah bahwa tidak ada peristiwa yang paling sibuk bila dibandingkan dengan kesibukan rakyat yang memiliki anak gadisnya dalam mencarikan perjaka ataupun duda untuk menjadi suami dari anak gadisnya itu. Sebagaimana hasil wawancara kepada (Sitira, Wawancara 4 Juni 2005) bahwa "Ada beberapa orang yang mengalami pernikahan berontak disini (Daru-Sila), orang tuanya sangat sibuk mencarikan jodoh bagi anak gadisnya”. Ia mencontohkan seseorang yang bernama Aminah yang terpaksa harus dinikahkan oleh orang tuanya dengan seorang lelaki (yang telah mempunyai dua isteri) yang tida memilik anak yang bernama Haji Mansyur.

Kasus yang sama juga dijelaskan oleh (Hamilah, wawancara 30 Mei 2005), bahwa "Dalam hal Nikah Berontak ini, orang tua dari pihak perempuan berusaha untuk mencari seorang laki-laki yang dijadikan sebagai suami anak perempuannya".
Tampaknya kasus semacam ini juga sudah membentuk memori kolektif yang masih teringgat sampai sekarang, betapa Kawin Berontak itu melanda masyarakat Bima kala itu.

Aminah menjelaskan bahwa Pada jaman Jepang, bagi mereka (perempuan Bima), memiliki beban tersendiri, mereka selalu kawatir akan diambil oleh Dou Nipo (Nippon) dan terpaksa harus menempuh cara Nikah Berontak, sehingga saat itu banyak anak-anak gadis yang kawin dibawah umur (Samudra, 1999, hal. 73). Bahkan kadang ada orang tua perempuan menempuh jalan melamarkan laki-laki untuk anak perempuannya, meskipun hal itu melanggar adat masyarakat setempat. Ada juga wanita dari golongan biasa yang bersedia mengorbankan diri manjadi Gundik Nippon, asalkan Nippon tidak memasuki halaman Istana Kesultanan dan tidak menngganggu Putri Sultan. Perempuan-perempuan ini dengan terpaksa melayani kepuasan Tentara Nippon dari satu tempat ke tampat lainnya.

Penjelasan tersebut diatas menunjukkan betapa terjadi gonjangan bathin di kalangan gadis-gadis Bima oleh karena harus manikah di bawah umur dan melanggar adat sekalipun. Sementara di satu sisi perempuan-perempuan dari golongan masyarakat biasa terpaksa harus merelakan dirinya menjadi para Gundik demi menjaga kesucian Putri Sultan. Hal yang terakhir ini berkaitan dengan upaya mempertahankan kewibawaan Kesultanan Bima yang sangat dijunjung tinggi oleh masyarakatnya. Tindakan-tindakan yang semakin membuat sikap antipati terhadap pemerintah pendudukan Jepang dikalangan masyarakat Bima ialah pelaksanaan kerja paksa atau Romusha dan penggambil alihan harta benda milik masyarakat oleh pemerintahan Jepang. Berbagai tindakan yang dialamatkan kepada masyarakat Bima tersebut pada akhirnya berbuntut terjadinya sikap pembangkangan terhadap kebijakan-kebijakan pemerintah 
Jepang oleh masyarakat Bima yang ditengarai oleh para laskar.

Sikap pembangkangan itu dilakukan dengan aksi-aksi Gerilya pada malam hari, dengan tujuan utama yaitu tempat-tempat penyimpanan senjata tentara Jepang. Adapun aksi itu seperti yang dilakukan oleh masyarakat yang terjadi di sekitar Temba Oi Mbo Nggaro Lembo Nggembe. Aksi masyarakat tersebut dilakukan bersama pasukan Laskar Bima. Hal ini sebagaimana dituturkan oleh salah seorang informan yang merupakan pelaku sekaligus saksi sejarah, bahwa :

"Pada malam itu, kami melakukan pencurian senjata dibawah pimpinan Yasin Bakara. Banyak tentara Nippon yang kami bunuh dan mayatnya dimasukkan kedalam sumur, kemudian dibakar. Hal ini dilakukan atas kerjasama antara tentara Heiho dan Laskar Bima (mantan tentara KNIL yang nasionalis). (Saleh, Wawancara 30 Mei 2005).

Aksi serupa juga terjadi di daerah Ntana-Donggo, ketika tentara-tentara Nippon sedang tertidur. Setelah melakukan aksinya dan berhasil membunuh beberapa orang tentara Nippon, mereka yang terlibat dalam aksi penyerangan itu kemudian lari masuk ke hutan dan bersembunyi. (Samiung, Wawancara 1 Juni 2005).

Meskipun tidak disajikan semua kasus-kasus yang terjadi sehubungan dengan aksi perlawanan rakyat terhadap tentara Jepang, namun minimal kedua kasus tersebut dapat memberikan gambaran tentang bentuk reaksi perlawanan masyarakat Bima terhadap Jepang. Selama terjadinya aksi-aksi perlawanan tersebut, sumuanya dilakukan dengan taktik Gerilya atau tidak berhadapan secara langsung dalam sebuah pertempuran malawan tentara Nippon oleh karena pertimbangan persenjataan yang minim.

Taktik gerilya yang dimaksud ialah menyerang ketika musuh dalam keadaan tidak siap atau lengah (antara lain tidur) dan menyingkir ketika musuh dalam keadaan siaga. Untuk melakukan taktik ini, tentunya yang perlu diketahui ialah pusat-pusat kekuatan musuh dan tempat-tempat yang menjadi sasaran penyerangan nantinya, agar aksi yang dilakukan tidak diketahui oleh tentara Jepang karena tidak memungkinkan bagi para masyarakat (Laskar) untuk berhadapan langsung dengan pihak Jepang.

\section{Dampak Pendudukan Militer Jepang di Bima}

\section{Kehidupan Sosial}

Nikah Berontak (Nika Baronta) merupakan salah satu masalah sosial yang timbul pada masa pemerintahan pendudukan Jepang di Bima. Terjadinya Nika Baronta disebabkan adanya keinginan tentara Jepang untuk mengambil dan memperkerjakan gadis-gadis Bima di bar-bar dan sekaligus melayani kepuasan hawa nafsu tentara Jepang. Keinginan tersebut mendapat tantangan dari pemerintah Kesultanan Bima yang fanatik dengan agama Islam dan adat setempat yang dijunjungnya. Atas dasar agama dan adat itulah, masyarakat Bima lebih memilih untuk melakukan Nika Baronta, sekalipun terkadang harus berseberangan dengan adat yang mereka pahami selama ini. Oleh Karena keadaan yang terjepit dan mendesak, sebagian dari orang tua (yang memiliki anak gadisnya) terpaksa harus (melanggar adat) mencarikan laki-laki Bima untuk dijadikan sebagai suami dari anak-anak gadis mereka. Bahkan, seorang lelaki yang sudah punya isteri sekalipun rela dijadakan sebagai suami anak gadisnya. Sampai pada tahap ini pertimbangan adat tampaknya "diabaikan" sementara waktu, dari pada anak gadisnya harus diserahkan kepada tentaratertara Jepang untuk dijadikan penghibur pada tempat-tempat yang telah ditentukan.

Hal lain yang dilakukan oleh pemerintah pendudukan Jepang terhadap rakyat Bima adalah praktek Kerja Wajib atau Romusha yakni pengerahan tenaga secara 
besar-besaran dengan secara paksa untuk mengerjakan pekerjaan pembangunan jalanjalan, benteng-benteng pertahanan, pos-pos kamp tentara Jepang, pembudidayaan tanaman, yang diharuskan kepada semua masyarakat Bima. Jika ada masyarakat yang melawan atau tidak mau bekerja sesuai dengan instruksi tentara Jepang, mereka mendapat siksaan dan bahkan tidak segan tentara Jepang melakukan pembunuhan kepada yang bersangkutan. Tindakan tersebut sungguh merupakan sesuatu yang tidak manusiawi, seperti ungkapan J. J Rosseau dalam Bukunya de Contrac Social bahwa "Setiap manusia mempunyai hak-hak yang sama dalam hal kebebasan, persamaan hak dan kemerdekaan”. Namun demikian, hal itu tidak mendapat perhatian dari tentara Jepang, sebab yang terpenting bagi mereka ialah bagaimana cara melakukan mobilisasi sumber daya manusia dan sumber daya alam yang ada demi kepentingannya dalam menciptakan lingkungan persemakmuran Asia Timur Raya dibawah pimpinan Jepang sebagai The Leader of Asia, The Flight of Asia, and The Protector of Asia. "Secara ekonomis memang Indonesia cukup menyediakan sumber daya alam yang memadai sebagai bahan mentah kebutuhan Industri Jepang” (Jhumhur, 1974, hal. 327)

\section{Dampak Pada Pendidikan}

Dalam sektor pendidikan pada masa pendudukan Jepang, terjadi perubahanperubahan yang mendasar. Untuk mengetahui hal tersebut kita simak kutipan wawancara berikut :

"Orang Jepang waktu itu tidak melakukan pembedaan antara sekolahnya orang-orang kaya dengan orang miskin (Dualisme Penddidikan) seperti yang pernah dilakukan oleh orang Belanda terhadap orang Bima. Orang Jepang juga memberikan kebebasan bagi masyarakat Bima untuk menggunakan bahasa Indonesia (walau bahasa Bima sekalipun), baik sebagai bahasa resmi sehari-hari maupun sebagai bahasa pengantar di sekolahsekolah. Namun, dalam perkembangan selanjutnya bahasa Jepang juga digunakan dalam kehidupan sehari-hari terutama bagi para pekerja. Walaupun ada kebebasan yang diberikan oleh orang Jepang menyangkut masalah pendidkan, namun anak-anak yang mau sekolah pada masa itu kurang" (Sihaka, Wawancara 30 Mei 2005).

Tidak hanya itu, suatu jenjang pendidikan sekalipun diganti dari bahasa belanda menjadi bahasa Jepang. Hal ini sesuai dengan ungkapkan oleh (Tajib, 1995, hal. 323) dan (Kamar, 2005, hal. 62) Depdikbud sebagai berikut :

"Hollands Inlandse Schoo (HIS)--lama pendiddikan 7 tahun, dirubah menjadi Kokumin Gakko, Vervoolk School menjadi Futsu Kugakko, Sekolah Guru atau Kweek School menjadi Syoto Sihau Gakko atau Kyom Yoseiso, Madrasah Islam menjadi Islam Gakkuia, Sekolah Pertukangan menjadi Kagyo Gakko, Sekolah Teknik Menengah menjadi Kagio Somen Gakko dan Sekolah Pertanian menjadi Nogyo Gakko”.

Didalam bidang bina raga (olah raga) pun, pemerintah Jepang memberikan latihan kepada masyarakat yakni Taiso (Senam) dan Tenko (Apel Pagi), yang diwajibkan kepada setiap pelajar (siswa) sebelum mereka memasuki ruangan (kelas). Demikian pula pada pagi hari, pengibaran bendera Jepang HINOMARU sudah menjadi keharusan dan diiringi dengan lagu kebangsaan Jepang KIMIGAYO. Masih dalam rangkaian apel pagi, diakhiri dengan KENKEIRI yaitu para peserta (siswa) diharuskan menghadap matahari terbit (negheningkan cipta) dalam rangka menajatkan keselamatan atas Tenno Heika (pimpinan tertinggi yang dianggap sebagai titisan dewa bagi masyarakat Jepang) yang berada di Tokyo. Para siswa juga diharuskan untuk mennguasai bahasa Jepang dan nyanyian-nyanyian yang berorientasi pada 
penyanjungan bangsa Jepang seperti yang sempat dinyanyikan oleh (Saleh, Wawancara 30 Mei 2005) dengan syairnya :

Pandanglah fajar di laut timur

Matahari tertinggi bersinar-sinar

O... bagaimana juga di gunung Fuji

Tiada cacat sedikit juga

Inilah kehormatan saudara Dai Nippon

Penggunaan bahasa Jepang dalam kehidupan sehari-hari masyarakat mamiliki tujuan agar masyarakat "menyatu" jiwanya dengan tata cara dan pola hidup bangsa Jepang.

\section{Kondisi Perekonomian}

Pada awal kedatangannya, pemerintahan pendudukan Jepang belum manampakkan kegiatan yang bersentuhan dengan perekonomian masyarakat Bima. Namun hal itu tidak berlangsung lama, sebab memasuki bulan kedua sejak kedatangannya di Bima, Jepang sudah mulai menyentuh persoalanpersoalan Ekonomi yang ditandai dengan instruksi menanam pohon Jarak. Ismail (1996 : 12). Instruksi pemerintah Militer Jepang ini untuk menanam pohon jarak adalah guna memenuhi keperluan perang Asia Timur Raya. Pohon Jarak ini sangat berguna bagi Militer Jepang yakni dipergunakan sebagai bahan bakar pesawat terbang Angkatan Udara Jepang.

Instruksi tersebut membuat rakyat harus melakukan aktifitas penanaman jarak agar terhindar dari tindakan-tindakan (hukuman) tentara Jepang. Dampaknya bagi masyarakat ialah semakin sempitnya lahan pertanian masyarakat yang digunakannya untuk menanam padi, jagung, sayur dan lain sebagainya. Sesuai dengan instruksinya, 75\% tanah milik rakyat harus ditanami pohon Jarak, selebihnya itu digunakan untuk menanam tanaman lainnya (Hakim, 4 Juni 2005). Dengan demikian, hal itu tentunya mempengaruhi hasil produksi pertanian masyarakat.

Perlu diketahui bahwa, Bima merupakan salah satu daerah yang sebagian besar penghasilnnya dari sektor pertanian, dengan dikeluarkannya instruksinya tersebut secara otomatis mempengaruhi pula kondisi perekonomian masyarakat. Penanaman pohon jarak memang tidak dirasakan manfaatnya bagi masyarakat Bima sebab tidak dapat dikonsumsi (secara langsung) untuk keperluan hidup sehari-hari. "Bagi mereka yang memiliki lahan untuk menanam pohon Jarak, diwajibkan kepadanya untuk menanam dilingkungan (halaman) rumahnya" (Ubu, wawancara 21 Mei 2005). Selain itu, pemerintahan pendudukan Jepang juga merampas harta benda kepunyaan penduduk yang digunakan untuk menyuplai bahan makanan selama berlangsungnya perang Asia Timur Raya. Mengenai hal itu dapat disimak pada kalimat berikut :

"Beras dan bahan pokok keperluan sehari-hari hilang dari pasaran sementara padi yang disembunyikan dirumah-rumah penduduk dan lumbung padi diperiksa oleh Kempeitai serta dicatat. Tidak lama berselang, Kempeitai-pun datang unutk mengambil barang-barang tersebut guna keperluan perang. Sementara Sawah tidak dapat digarap dengan baik, sebab masyarakat selalu diliputi perasan takut akan serangan udara sewaktu-waktu. Ditambah pula kenyataan yang harus mereka terima, yakni ketika datang musim panen, Kempeitai datang mencatat hasil panen dan selanjutnya diangkut untuk kepentingan saudara Tua”. (Tajib, 1995, hal. 323)

Keberhasilan dalam melakukan pencarian barang-berang kepunyaan masyarakat tersebut tidak terlepas dari keberadaan penduduk setempat yang merupakan "kaki tangan" atau orang yang diperkerjakan oleh pemerintah Jepang. Dengan adanya mereka ini membuat masyarakat kesulitan untuk menyembunyikan harta bendanya walau dimanapun. Pengangkatan beberapa orang warga dalam sistem pendudukan Jepang tujuannya adalah agar Jepang tidak bersentuhan langsung dengan masyarakat dalam hal kebijakan yang dikeluarkannya. Alhasil, bila masyarakat 
marah dan mencoba melawan dengan dalih penderitaan dan kesengsaran mereka tentu akan marah dengan para Kempeitai tersebut yang jelas-jelas sama statusnya seperti mereka (masyarakat). Mereka adalah serumpun (sekaum) dan bahkan masih mempunyai hubungan kekeluargaan dengan warga yang diperintahkan untuk bekerja. Dengan demikian pemerintahan Jepang terhindar dari ancaman-ancaman yang sewaktu-waktu datang yang terkait dengan kebijakan praktek kerja wajib (Romusha) dan berbagai kebijakan lainnya.

\section{Kesimpulan}

Sebagai penutup, sekurang-kurangnya ada tiga hal yang dapat dijadikan kesimpulan. Ketiga hal tersebut adalah. Pertama, Gerak pemerintahan pendudukan Jepang di Bima memiliki kesamaan dengan daerah-daerah lain di Indonesia dalam arti bahwa kedatangannya dibalut dengan janji-janji manis yang didesain sebagai propaganda kepada masyarakat Bima (Misalnya ingin membebaskan masyarakat Bima dari unsur bangsa Barat-Belanda), sehingga awal kedatangannya (17 Juli 1942 dibawah pimpinan Kolonel Saito) tidak dicurigai dan bahkan mendapat sambutan yang baik. Hal itu didukung pula olah situasi ketika itu. Masyarakat Bima trauma terhadap penjajahan Belanda, meskipun sebelum kedatangan Belanda, Belanda telah berhasil diusir dari tanah Bima "Mbojo" berkat usaha dari laskarnya.

Kedua, Meskipun pada awal kedatangannya disambut baik (simpati) oleh masyarakat Bima, namun memasuki bulan kedua masa pemerintahan pendudukannya, tampak adanya motivasi dan keinginan Jepang yang sesungguhnya (dalam rangka mencitakan Persemakmuran Asia Timur Raya) melaui praktek pendudukannya berupa kerja Wajib (Romusha). Romusha ini ditujukan untuk menghimpun sumber daya alam yang ada guna mendukung kelengkapan dan strategi Jepang menghadapi sekutu di
Asia Tenggara pada perang "Dai Toa No Senso" (Asia Timur Raya).

Ketiga, Praktek pendudukan pemerintahan Jepang di Bima telah menimbulkan berbagai dampak bagi kehidupan Sosial dan Ekonomi masyarakat. Dibidang sosial diantaranya terjadi keresahan sosial dan porak-porandanya tata kehidupan sosial masyarakat. Agama dan adat yang selama ini dijunjung tinggi oleh masyarakat "terpaksa" harus dilanggar. Sementara dampak dibidang Ekonomi, berupa keterpurukkan Ekomomi, sebab masyarakat tidak lagi mencurahkan perhatian sepenuhnya untuk mengolah lahan pertaniannya. Penderitaan masyarakat berakhir setelah Jepang kalah dan menyerah tanpa syarat kepada sekutu pada bulan Agustus 1945. Sejak itu, pemerintahan pendudukan Jepang berakhir di Bima khususnya dan Indonesia pada umumnya.

\section{Daftar Pustaka}

Hakim, H. (4 Juni 2005). wawancara. Bima: Hasil wawancara Pribadi.

Hamilah. (wawancara 30 Mei 2005). Wawancara mengenai Nikah Barontak.

Bima: oleh Pribadi.

Ismail, M. H. (1996). Sejarah Mbojo Bima: dari Zaman Naka sampai Zaman Kemerdekaan. Bima-NTT: PT Agung Perdana.

Jafar, M. (2005). Wawancara. Bima: hasil Wawancara.

Jhumhur, I. H. (1974). Sejarah Pendidikan. Bandung: Bina Ilmu.

Kamar, I. D. (2005). Sejarah Pendidikan. Makassar: Rineka Cipta.

Kertaparti, S. (2000). Sekitar Proklamasi 17 Agustus 1945. Jakarta: Pustaka Pena.

Madjid, M. D. (2014). Ilmu Sejarah Sebuah Pengantar. Jakarta: Prenada Media Group.

Notosusanto, N. (1992). Sejarah Nasional Indonesia Jilid VI. Jakarta: Depdikbud. 
(C) Jurnal Pemikiran Pendidikan dan Penelitian Kesejarahan

Ricklefs, M. (1995). Sejarah Indonesia Modern. Yogyakarta: UGN Press.

Saleh, Y. (Wawancara 30 Mei 2005). wawancara. Bima: Peribadi.

Samiung, I. (Wawancara 1 Juni 2005). Wawancara. Bima: Pribadi.

Samudra, P. (1999). Bunga Rampai Pengembangan Budaya Bima. Jakarta: Aditya Media-FP3DM.

Sihaka, H. (Wawancara 30 Mei 2005). wawancara. Bima: Pribadi.

Sitira, H. (Wawancara 4 Juni 2005). Wawancara. Bima: Olah data wawancara pribadi.
Sjamsuddin, H. (2012). Metodologi Sejarah. Yogyakarta: Ombak.

Soebantardjo. (1962). Sari Sejarah AsiaAustralia. Jakarta: Bobkri.

Tajib, A. (1995). Sejarah Bima-Dana Mbojo. Jakarta: Sinar Harapan.

Ubu, L. L. (wawancara 21 Mei 2005). wawancara. Bima: Pribadi.

Zakaria. (29 Mei 2005). Wawancara. Bima: oleh penulis. 